Fountain Journal of Natural and Applied Sciences: 2015; 4(1): 19 - 26

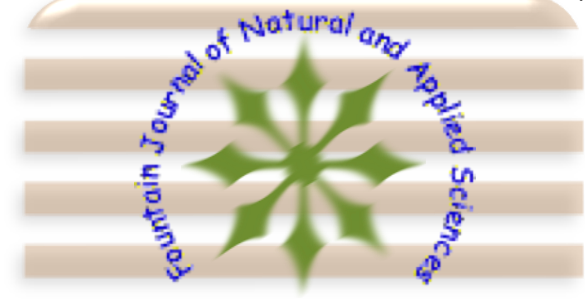

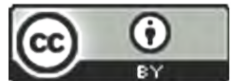

This work is licensed under Creative Commons Attribution 4.0 International License.

DOI: $10.53704 /$ fujnas.v4i1.52

A publication of College of Natural and Applied Sciences, Fountain University, Osogbo, Nigeria

Journal homepage: www.fountainjournals.com

ISSN: 2354-337X (Online), 2350-1863 (Print)

\title{
Microbiological Quality and Safety of pre-cut fruit retailed in Ilorin, Kwara State, Nigeria.
}

\author{
Odebisi-Omokanye*, M.B., Oke, M.A., Ahmed El-Imam, A. M., Ajijolakewu, A.K., \\ Salaudeen, B.I. \\ Department of Microbiology, Faculty of Life Sciences, University of Ilorin, P.M.B. 1515, Ilorin, Nigeria.
}

\begin{abstract}
The microbiological quality of pre-cut fruits retailed in three local markets in Ilorin, Kwara state, Nigeria was assessed. Pre-cut fruit samples comprising watermelon, pineapple and pawpaw were obtained from vendors at different retail outlets in the markets and the physicochemical and microbiological characteristics were examined. Mean total aerobic plate count ranged from $1.20 \times 10^{4}$ to $2.0 \times 10^{4} \mathrm{cfu} / \mathrm{g}$ while fungal count ranged from $0.5 \times 10^{2}$ to1.6 $\times 10^{2} \mathrm{cfu} / \mathrm{g}$. Eight bacterial and six fungal species were isolated: Proteus vulgaris, Staphylococcus aureus, Bacillus subtilis, Pseudomonas aeruginosa, Campylobacter jejuni, Klebsiella aerogenes, Escherichia coli, Salmonella spp. Aspergillus niger, Aspergillus flavus, Mucor mucedo, Rhizopus stolonifer, Aspergillus fumigatus and Saccharomyces cerevisiae. The physicochemical parameters studies varies as follows: $\mathrm{pH}$ ranged from 3.5 to 4.1, moisture content 60.20 to $90.73 \%$, titratable acidity 0.42 to $0.80 \mathrm{~g} / 100 \mathrm{ml}$, ash 0.50 to $1.11 \%$ and total sugar 2.01 to $2.53 \mathrm{~g} / 100 \mathrm{ml}$. The findings from this study showed that the fruits contained microorganisms that are potentially pathogenic. Under favourable conditions, they may multiply and thus render the fruits unsafe for consumption as they could become means of food poisoning.
\end{abstract}

Keywords: Food poisoning, Food vendors, pre-cut fruit, food contamination

\section{Introduction}

Fruits are an extraordinary dietary source of nutrients, vitamins and fibre for humans and are thus vital for health and well being. Well balanced diets, rich in fruits have been reported to have the ability to prevent vitamin $C$ and vitamin $A$ deficiencies reduce the risk of several diseases (Kalia et al., 2006). Fruits contamination with pathogens from human and/or animal sources can occur at various stages along the food chain.

Pre-cut fruits refer to fruits that have been cut open, sliced into pieces but remain in the fresh state and are stored or displayed for sale or for serving in retail outlets (Kaplan and Campbell, 1982; Lund, 1992; De Roever, 1998). They are usually packaged in polyethylene bags and sold by street vendors or at local markets without the need to cut or rinse before consumption. Their

*Corresponding author: +2348034006111

Email address: odebisimutiat@yahoo.com 
increased consumption coupled with the associated risk of disease to which consumers may be exposed, is a matter of great concern. Most times, it is difficult for one to attest to the hygiene of the processors or the sanitary conditions at points of preparation. Moreover, the case is worsened by the fact that sliced fruit street vending is done without adequate storage conditions, thereby exposing the sliced fruits to flies and other disease causing agents (Barro et al., 2007).

Over the last few years, there has been a significant increase in the consumption of pre-cut fruits in Nigeria. These pre-cut fruits are processed and sold by unlicensed vendors who lack proper education and know little about food hygiene (Muinde and Kuria, 2005). The consumption of pre-cut fruits may thus potentially increase the risk of food-borne diseases (Mensah et al., 1999).

This study was conducted in order to assess the microbiological and physicochemical quality of ready-to-eat pre-cut fruits sold in Ilorin, Kwara State, Nigeria, in order to highlight the health implications of consuming such fruits.

\section{Materials and Methods Collection of Samples}

Samples were collected from three different markets (Oja Oba, Oja Ipata and Yoruba Road) in Ilorin. These three vending sites were chosen because they are the major markets relied upon by many fruit vendors for their sales. The fruits studied were watermelon, pineapple and pawpaw. Nine samples of each fruit type (a total of 27 samples) were purchased from different vendors who hawked the items in the markets. All the samples wrapped in nylons as displayed by the vendors were collected in sterile sampling polyethylene bags. They were transported in an ice pack to the laboratory for processing within 30 minutes to $1 \mathrm{hr}$ of collection.

Isolation and Enumeration of Bacteria and Fungi Each fruit sample was homogenised by crushing $1 \mathrm{~g}$ of sample in $10 \mathrm{ml}$ of sterile distilled water using a sterile porcelain mortar and pestle. Ten-fold serial dilution of the resultant homogenate was prepared by transferring $1 \mathrm{ml}$ of the suspension into $9 \mathrm{ml}$ of sterile diluent. The total aerobic plate counts for the samples were determined by plating $0.1 \mathrm{ml}$ of $10^{-2}$ and $10^{-3}$ dilutions on sterile MacConkey and Nutrient agar plates using the pour plate method. For the fungal counts, $0.1 \mathrm{ml}$ of $10^{-1}$ and $10^{-2}$ dilutions were plated on Potato Dextrose Agar (PDA). The MacConkey agar and Nutrient agar plates were incubated at $37{ }^{\circ} \mathrm{C}$ for $48 \mathrm{hrs}$ to obtain the total viable bacterial counts, PDA plates were incubated at 25 ${ }^{\circ} \mathrm{C}$ for $72 \mathrm{hrs}$ to obtain the fungal counts.

Discrete colonies appearing at the end of the incubation period were counted using a digital illuminated colony counter. Colonies of bacteria that developed on the plates were then identified using both morphological and biochemical methods (Fawole and Oso, 1986). The fungi were identified using colonial morphology and microscopy. The counts were expressed as colony forming units per gram (cfu/g) of the sample.

\section{Physicochemical Analysis \\ pH Determination}

The method of Kirk and Sawyer (1991) was followed in determining the $\mathrm{pH}$ of the fruits. Five grams of each fruit sample was weighed and dispensed into $50 \mathrm{ml}$ of distilled water in a sterile conical flask. The suspension was properly mixed and allowed to settle. It was then filtered and the $\mathrm{pH}$ of the extract was taken using a clider instrument (Thermos Fischer. Uk) pH meter.

\section{Determination of Titratable acidity}

Five grams of each ground sample of fruit was dispersed into $50 \mathrm{ml}$ of distilled water. It was mixed thoroughly and left for some time so as to settle, which was then filtered. Twenty $\mathrm{ml}$ of the filtrate was pipetted into a conical flask, 2drops of phenolphthalein was added as indicator and it was titrated against $0.1 \mathrm{M}$ sodium hydroxide. The volume of sodium hydroxide used was noted (Nielson, 1998). Titratable acidity was expressed as $\mathrm{g} / 100 \mathrm{ml}$. 
Table 1: Physicochemical Characteristics of Pre-cut Fruit Samples from each Market.

\begin{tabular}{llllll}
\hline Sample & Ash\% & $\mathrm{pH}$ & Moisture\% & $\begin{array}{l}\text { Titratable } \\
\text { acidity } \mathrm{g} / 100 \mathrm{ml}\end{array}$ & $\begin{array}{l}\text { Total sugar content } \\
\mathrm{g} / 100 \mathrm{ml}\end{array}$ \\
\hline Pineapple & & & & & \\
A & $1.11 \pm 0.10$ & $3.8 \pm 0.1$ & $80.6 \pm 0.5$ & $0.599 \pm 0.003$ & $2.06 \pm 0.02$ \\
B & $1.03 \pm 0.02$ & $3.6 \pm 0.2$ & $80.6 \pm 0.5$ & $0.802 \pm 0.25$ & $2.06 \pm 0.02$ \\
C & $1.02 \pm 0.02$ & $3.7 \pm 0.2$ & $80.6 \pm 0.5$ & $0.597 \pm 0.005$ & $2.05 \pm 0.004$ \\
Watermelon & & & & & \\
A & $0.68 \pm 0.08$ & $4.0 \pm 0.2$ & $90.44 \pm 0.8$ & $0.483 \pm 0.02$ & $2.06 \pm 0.20$ \\
B & $0.50 \pm 0.01$ & $3.9 \pm 0.1$ & $90.40 \pm 0.7$ & $0.505 \pm 0.01$ & $2.07 \pm 0.01$ \\
C & $0.55 \pm 0.03$ & $4.0 \pm 0.2$ & $90.73 \pm 0.6$ & $0.488 \pm 0.007$ & $2.12 \pm 0.14$ \\
Pawpaw & & & & & \\
A & $0.74 \pm 0.06$ & $3.7 \pm 0.3$ & $60.3 \pm 0.3$ & $0.463 \pm 0.03$ & $2.53 \pm 0.12$ \\
B & $0.74 \pm 0.01$ & $3.5 \pm 0.1$ & $70.3 \pm 0.2$ & $0.415 \pm 0.01$ & $2.19 \pm 0.09$ \\
C & $0.70 \pm 0.02$ & $4.1 \pm 0.1$ & $60.2 \pm 0.1$ & $0.486 \pm 0.005$ & $2.49 \pm 0.10$ \\
\hline N & & & &
\end{tabular}

$\mathrm{N}=3$ mean \pm standard deviation

Key: $A=$ Samples from Oja Oba,$B=$ Samples from Oja Ipata, $C=$ Samples from Yoruba Road market

\section{Determination of Moisture Content}

Five grams of each fruit sample was measured and transferred into an oven dried crucible. The sample was then dried in an oven at $105^{\circ} \mathrm{C}$ and weighed at interval of 1 hours. This was repeated until a constant weight was attained (AOAC, 1980). The difference in weight gives the moisture content of the sample and it was expressed as a percentage thus:

$\%$ Moisture content $\frac{\text { Loss in weight due to drying }}{\text { Original weight of sample }} \times 100$

\section{Determination of ash content}

Two grams of each fruit sample was weighed into a sterile crucible of a known weight and then placed in a furnace which was set at $600^{\circ} \mathrm{C}$ for 2 hours during which the whole samples burnt into ash. The furnace was left to cool. Using a pair of forceps, the samples were brought out. The weights of the samples were determined using a weighing balance (AOAC, 1980). The percentage ash content was calculated thus:

$\%$ Ash content $=\frac{\text { Loss in weight of sample }}{\text { Original weight of sample }} \times 100$

\section{Total sugar content determination}

One gram of the sample was weighed and ground using a percolation mortar and pestle. It was then transferred into $10 \mathrm{ml}$ of water and mixed thoroughly. One milliltre of the extract was then transferred into a test tube. To this was added $5 \%$ phenol $(1 \mathrm{ml})$ and $5 \mathrm{ml}$ of conc. $\mathrm{H}_{2} \mathrm{SO}_{4}$ while carefully dispensing the acid to the side of the tube for thorough mixing. The mixture was allowed to stand for 10 minutes. The tube was then placed in a water bath to boil at $28{ }^{\circ} \mathrm{C}$ for 30 minutes. The absorbance was read in a spectrophometer at $490 \mathrm{~nm}$ wave length (AOAC, 1980).

\section{Results}

Table 1 shows the physicochemical characteristics of the pre-cut fruit samples from the three markets. The ash content ranged from 
0.50 to $1.11 \%$; pH varied between 3.5 and 4.1; moisture content ranged from 60.20 to $90.73 \%$, titratable acidity 0.42 to $0.80 \mathrm{~g} / 100 \mathrm{ml}$ and total sugar 2.01 to $2.53 \mathrm{~g} / 100 \mathrm{ml}$.

The results showed that the highest bacterial count of $2.0 \times 10^{4} \mathrm{cfu} / \mathrm{g}$ was obtained from the pre-cut water melon sample gotten from Oja Oba market while the lowest bacterial count of $1.2 \times 10^{4} \mathrm{cfu} / \mathrm{g}$ was obtained from the pre-cut pawpaw obtained from Yoruba Road (Table 2). The pre-cut fruit samples in this study were found to harbour a total of eight bacterial species. These were Staphylococcus aureus, Proteus vulgaris, Bacillus subtilis, Pseudomonas aeruginosa, Campylobacter jejuni, Klebsiella aerogenes, Escherichia coli and Salmonella sp. (Table 3). Six fungi were isolated and they were Aspergillus niger, Aspergillus flavus, Mucor racemosus Rhizopus stoloniter, Aspergillus fumigatus and Saccharomyces cerevisae (Tables 3\&4).

Tables 3 and 4 show the percentage frequency of occurrence of bacterial and fungal isolates. Staphylococcus aureus was the most frequently occurring bacterial isolate (28\%) while the least occurring was Campylobacter jejuni (3\%) (Table 3).
The most frequently occurring fungal isolate was Aspergillus niger (33\%) while Rhizopus stolonifer was the least occurring $(6 \%)$ as represented in Table 4.

\section{Discussion}

These results show that the samples were not wholesome (despite their aesthetics), as the pre-cut fruits were contaminated with bacteria and fungi that have various health implications. The presence of microorganisms of public health importance in the sampled pre-cut fruits could be a reflection of the level of exposure and the handling processes in these vending sites. In the market, the products are opened as often as the customer's demand, thus encouraging frequent visits by flies. The practice of using the same bucket of water to wash all the fruits (if it is ever washed at all) is common place in many markets (Khali and Mazhar, 1994) and this could possibly account for the observed contaminations. Other reasons that could be adduced for the observed level of contamination include cross contamination caused by the repetitive use of same unclean utensils for different fruits during cutting (Centre for Disease Control and Prevention, 1979) and microbial invasion during processing, packaging and marketing (Barro et al., 2006).

Table 2: Total Microbial Count of Pre-cut Fruit Samples

\begin{tabular}{lll}
\hline Sample & $\begin{array}{l}\text { Bacterial Count (cfu/g) } \\
10^{4}\end{array}$ & $\begin{array}{l}\text { Fungal Count (cfu/g) } \\
\times 10^{2}\end{array}$ \\
\hline Pineapple & & \\
A & 1.6 & 1.0 \\
B & 1.5 & 1.1 \\
C & 1.9 & 1.2 \\
Watermelon & & \\
A & 2.0 & 0.5 \\
B & 1.7 & 1.2 \\
C & 1.6 & 1.1 \\
Pawpaw & & \\
A & 1.3 & 1.6 \\
B & 1.4 & 0.6 \\
C & 1.2 & 0.7
\end{tabular}

Key: $A=$ Samples from Oja Oba; $B$ = Samples from Oja Ipata; $C$ = Samples from Yoruba Road 
Fountain Journal of Natural and Applied Sciences: 2015; 4(1): 19 - 26

Table 3: Frequency of Occurrence of Bacterial Isolates in Sampled Pre-cut Fruit.

\begin{tabular}{cc}
\hline Bacterial isolate & \% frequency \\
\hline Staphylococcus aureus & 28 \\
Bacillus subtilis & 25 \\
Pseudomonas aeruginosa & 14 \\
Proteus vulgaris & 6 \\
Salmonella sp. & 11 \\
Campylobacter jejuni & 3 \\
Klebsiella aerogenes & 8 \\
Escherichia coli & 5 \\
Total & 100
\end{tabular}

The organisms isolated in this study are of peculiar interest, because of their various involvements in different infections. Staphylococcus aureus which had the highest occurrence among bacteria in this study may have been introduced into the fruits through body contact by the handlers as this organism is a normal flora of the nasal passage, hands and skins of healthy individuals (Nester et al., 2010). The predominant occurrence of $S$. aureus as shown in this study is similar to that reported by Kumar and Ganguli (2006), where they reported high occurrence rate of $S$. aureus in food. This organism is known to produce enterotoxin leading to food intoxication (Nester et al., 2010). Bacillus subtilis is indicative of contamination from environmental sources either soil or air (Willey et al., 2010). It produces endospores, which can help it to survive heat treatment and is also associated with miscellaneous problems such as food poisoning (Drobniewski, 1993). Pseudomonas aeruginosa, Escherichia. coli, Klebsiella pneumoniae, Salmonella sp, Proteus vulgaris and Campylobacter jejuni are environmental contaminants. They have been isolated from plants, human skin, animal and dairy products.

\begin{tabular}{ll}
$\begin{array}{l}\text { Table 4: Frequency of Occurrence of } \\
\text { Fungal isolate }\end{array}$ & $\%$ frequency \\
\hline Aspergillus niger & 33 \\
Aspergillus flavus & 14 \\
Mucor mucedo & 11 \\
Rhizopus stolonifer & 6 \\
Aspergillus fumigates & 21 \\
Saccharomyces cerevisiae & 15 \\
Total & 100
\end{tabular}


Their presence in the sampled ready-to-eat precut fruits could be through unclean hands of the vendor, contact with sewage and faecal contaminated water (De Rover, 1998). These suggest that the samples could serve as a common vehicle for pathogens transmitted via the faecaloral route. The presence of Salmonella spp, E. coli, Klebsiella and Campylobacter jejuni calls for concern as these organisms are frequently associated with poor sanitary practices and could be a pointer to danger of possible food borne infection. E. coli and Salmonella spp are especially of faecal origin and have been implicated in numerous food borne diseases (Oranusi et al., 2006). Bacteria like Salmonella spp, Shigella spp., Campylobacter spp., and Escherichia coli can contaminate sliced fruits through contact with sewage and contaminated water (Blostein, 1991). Most of the contaminating bacteria isolated in this study could be associated with the general poor sanitary environmental conditions under which the fruits were handled (Little and Mitchell, 2004). The microbial quality of the fruits in their raw state are similar to the reports of Kuminos and Copeland (1972) who reported $P$. aeruginosa infection in a hospital via vegetables.

The presence of $A$. niger, $A$. flavus, $A$. fumigatus, R. stolonifer, M. mucedo and Penicillium $s p$. in these fruits buttresses the likelihood of contamination and are widely spread in nature (they are ubiquitous) found on fruits, vegetables and other substrates that provide nutrients. They can tolerate high concentration of sugar and salt. Some of the fungi, especially Aspergillus spp are able to survive in the absence of free water (Samson et al., 1981). Also, the production of spores by these organisms makes it possible for them to survive for some time on the fruits (Smith, 1960). Also aflatoxin produced by $A$. flavus, because of its carcinogenic potential and extreme liver toxicity, even at low concentrations is believed to pose a risk to human health. Consequently, presence of Aspergillus flavus in food commodities is perceived as a food safety issue (Lederbera, 1992). Similarly, the isolate
Rhizopus stolonifer causes food spoilage, grows on fruits, vegetables, breads and other food products. $R$. Stolonifer has been reported to cause elevation in $\mathrm{pH}$ beyond the safety value of 4.6 and makes the environment more conducive for the growth of pathogenic bacteria (Efiuviwevwere and Akoma, 1997). None of the fruit samples was mouldy suggesting that the fungi were yet to be established. If the moulds get established in the pre-cut fruits, mycotoxic substances which could be hazardous to consumers may be produced.

The fruits were found to contain bacteria and fungi which under favourable conditions which could multiply, leading to spoilage of these products and rendering them unwholesome. This could also become a vehicle of food poisoning or food infection.

\section{Conclusion}

This study shows that the sampled precut fruits are potential vehicles for the transmission of infections, especially those transmitted through faecal-oral route. The type of isolates and their distribution pattern showed that the pre-cut fruits get contaminated during slicing, rinsing and display for sale. It is therefore advised that hygienic practices be adopted by the fruit vendors. Hands should be properly and constantly washed when coming in contact with food. Utensils such as knife and trays used also should be cleaned and proper sanitation carried out regularly. Also, retailers and consumers are advised to wash fresh fruits properly before peeling, slicing or cutting and store cut fruits at 4 ${ }^{0} \mathrm{C}$ until sold or consumed. In addition, the government must have better surveillance on the activities of sliced produce street vendors in order to minimize the risk of disease outbreak associated with consumption of contaminated food produced.

\section{References}

Allwood, P.B., Jenkins, T., Paulus C., Johnson, L. and Hedberg, C.W. (2004). Hand washing 
compliance among retail food establishment worker in Minnesota. $J$. Food Prot., 12: 2825-2828.

(Association of Official Analytical Chemists) Official Method of Analysis W. Hortwitz $16^{\text {th }}$ Edition. (1980).

Barro N., Iboudo, I. and Traore, A.S. (2006). Hygienic status assessment of dishwater, utensils, hands and pieces of money in street food vending sites in Ouagadougou, Burkina Faso. Afr. J. Biotechnol. 5: 11071112.

Barro, N., Bello Abdou, I.R., Itsiembou, Y., Savadogo, A., Quattara, C. A. T., Nikiema, A.P., Desouza, C. and Traore, A.S. (2007). Street Vended Foods Improvement; Contamination, Mechanism and Application of Food Safety in Pakistan. Journal of Nutrition. 6(1):1-10.

Blostein, J. (1991). An outbreak of Salmonella javiana associated with consumption of watermelon. J. Environ. Health. 56 29-31.

Centre for Disease Control and Prevention (CDC) (1979). Salmonella oranienburg gastroenteritis associated consumption of pre-cut watermelons-Illinois Morbidity and Mortality Weekly Report, 28 522523.

De Rover, C. (1998). Microbiology safety evaluations and Recommendation on fresh produce J. Food control, 9(6) 321-347.

Drobniewski, F. A. (1993). Bacillus cereus and related species. Clin. Microbiol. Rev. 6: 324-338.

Efiuvwevwere, B.J. O. and Akoma, O. (1997). Microbiological studies on a Nigerian Maize Product, Kwoka supplemented with soybean. J. Food Safety 17:249-259.

Fawole M.O. and Oso B.A. (1986). Laboratory manual of Microbiology, Spectrum books Ltd, Nigeria, P. 34-35.

Kalia, A. and Gupta, R.P. (2006). Handbook of fruit and fruit processing, 1st Edition, Blackwell publishing, pp. 3-28.

Kaplan, J.E. and Campbell, D.S. (1982). Frequency of a Norwalk like pattern of illness in outbreaks of acute gastroenteritis. America Journal of Public Health, 72: $1329-1332$.

Kirk, C. and Sawyer, R. (1991). Longman scientific and technical; hallow Essex U.K. Pearson's chemical analysis of food $9^{\text {th }}$ ed.

Kumar, M. and Ganguli, A. (2006). Microbiological safety of street vended fruits chats in patiala city Indian. Journal of medical microbiology., 24: 75-76.

Kuminos, S.D. and Copeland, C.E. (1972). Introduction of Pseudomonas aeruginosa into hospital via vegetables. Appl. Microbial., 24(4): 567- 70.

Little, C.L. and Mitchell, R.T. (2004). Microbiological quality of pre-cut fruits, sprouted seeds and unpasteurized fruit from retail and production premises in UK. Public Heaith, 7(3): 567-70.

Lund, B.M. (1992). Ecosystems in Vegetable foods Journal Applied Bacteriology., 73:115-135.

Lederberg, O.S. (1992). Fungal spoilage of fruits and fruit products. In food and beverage mycology $2^{\text {nd }}$ ed., Van Nostrand Reinhold, New York. PP. 101-128.

Muinde, O.K. and Kuria, E. (2005). Hygienic and Sanitary Practices of Vendors of Street Foods in Nairobi, Kenya. AJF AND 5:1-13.

Mensah ,P., Owusu-Darko, K., Yeboah-Manu, D., Ablordey, A., Nkrumah, F.K. and Kamiya, H. (1999). The role of street food vendors in transmission of enteric pathogens. Ghana Med. J. 33: 19-29.

Nielson, S.S. (1998). Aspen publisher Inc. Gaithesburg Maryland, U.S.A. Food analysis $2^{\text {nd }}$ ed.

Nester, E.W., Anderson, D.G., Roberts, C.E., Pearsall, N.W. and Nester, M.T. (2010). Microbiology: A Human Perspective, (3rd ed). McGraw Hill Plc., New York. p. 590.

Oranusi, S., Onyeike, E., Galadima, M. and Umoh, V.J. (2004). Hazard analysis critical control points of foods prepared by families in Zaria, Nigeria. Nig. $J$. Microbiol. 18(1-2) 346-362. 
Samson, R. A., Hoekstra, E. S. and Van Oorschot, C. A. N. (1981). Introduction to Food Borne Fungi. Pub: Central Bureau Voor Schimmelcultures Netherlands

Smith, G. (1960). An Introduction to Industrial Mycology. Edward Arnold (Pub.) Ltd. London. Pp399.
Willey, J. M., Sherwood, L. M. and Woolverton, C. J. (2010). Prescott, Harley and Klein's Microbiology, $7^{\text {th }}$ ed. McGraw Hill Companies, NY. pp 136. 